\title{
Link and Match sebagai Kebijakan Pendidikan Kejuruan
}

\section{Link and Match as a Vocational Education Policy}

\author{
Eka Prihatin Disas \\ Universitas Pendidikan Indonesia, Bandung, Jawa Barat, Indonesia \\ ekaprihatin@upi.edu \\ Naskah diterima tanggal 9/6/2018, Direvisi akhir tanggal 15/7/2018, disetujui tanggal 15/8/2018
}

\begin{abstract}
Abstrak
Penelitian ini dilatarbelakangi oleh masalah-masalah pengangguran tenaga terdidik menjadi sorotan masyarakat. Dibutuhkan suatu kebijakan yang dapat meningkatkan relevansi Sekolah Menengah Kejuruan (SMK) dengan kebutuhan dunia kerja, dunia usaha dan dunia industri. Penelitian ini menggunakan metode penelitian kualitatif dengan pendekatan penelitian studi kasus (case study) yang bertujuan untuk mempelajari secara intensif mengenai latar belakang masalah pengangguran dan bagaimana kebijakan link and match dapat menjadi solusi bagi masalah pengangguran. Hasil dalam penelitian ini akan memberikan gambaran luas dan mendalam mengenai kebijakan link and match, yaitu dengan adanya Link and Match tersebut Pendidikan Kejuruan dapat mengetahui kompetensi (keahlian) apa yang paling dibutuhkan dunia kerja dan kompetensi apa yang paling banyak dibutuhkan dunia kerja

Kata Kunci: pengangguran, link and match, kebijakan, pendidikan kejuruan.
\end{abstract}

\begin{abstract}
This research is motivated by the problems of educated unemployment in the public spotlight. A policy is needed that can increase the relevance of Vocational High Schools (SMK) to the needs of the world of work, business and industry. This study uses qualitative research methods with a case study approach which aims to study intensively about the background of the problem of unemployment and how link and match policies can be a solution to the problem of unemployment. The results in this study will provide a broad and in-depth picture of link and match policy, namely the existence of the Link and Match Vocational Education can find out what competence is most needed by the workforce and what is the most needed competence in the world of work.
\end{abstract}

Keywords: unemployment, link and match, policy, vocational education.

\section{PENDAHULUAN}

Merujuk hasil survei Badan Pusat Statistik (BPS) per Agustus 2016, terdapat lebih dari dari 182.99 juta orang tenaga kerja Indonesia, sebanyak 7.24 juta orang di Indonesia berstatus pengangguran. Mereka belum tertampung oleh dunia kerja. Tingkat pengangguran terbuka (TPT) paling besar adalah lulusan SMK sebesar 11.24\%, kemudian lulusan Sekolah Menengah Atas (SMA) mencapai 9.55\%, disusul lulusan Sekolah Menengah Pertama (SMP) tercatat
$7.15 \%$, sedangkan rasio lulusan SMK sejak tahun 2005 terus meningkat dan menyumbangkan pengangguran yang cukup tinggi.

Peserta didik menghadiri pendidikan di sekolah dan memilih bidang gelar dengan harapan berhasil di dalam dunia kerja. Tetapi salah satu aspek keberhasilan pasar kerja adalah kemampuan untuk memanfaatkan investasi apa yang didapat di sekolah dalam pekerjaan di masa depan (Robst, 2017). The quantity of schooling is only one way 
to consider the match between schooling and jobs. (Sloane, 2013)mengatakan bahwa workers may be mismatched if the level of schooling is appropriate but the type of schooling is not.

Selain itu, sebagian besar penelitian berkaitan dengan fenomena ketidak mampuan pekerjaan pendidikan melihat tingkat pendidikan (Boudarbat \& Chernoff, 2015). Saat seseorang bekerja dalam posisi di bawah tingkat studi seseorang, keterampilan yang dipelajari dalam pendidikan formal mungkin tidak sepenuhnya digunakan. Missmatch pendidikan terjadi secara vertikal yaitu antara tingkat pendidikan dan kebutuhan pekerjaan dan terjadi secara horizontal dimana terjadinya ketidakcocokan bidang studi yang diteliti dengan pekerjaan. Memperhatikan bidang studi yang dipelajari penting karena memungkinkan untuk menganalisis berbagai jenis keterampilan; Pendidikan tidak hanya menyediakan modal manusia secara umum, namun bidang studi tertentu memberikan ketrampilan spesifik pekerjaan untuk pasar kerja (Hersch, 2012; Walters, 2014).

Private sector business leaders believe that this mismatch is primarily due to the problems of educational structure, quality and the content of the educational system, particularly university system has failed to provide the required skills, aptitudes, and job orientation for the graduate workforce(Mf, Senarath, \& Patabendige, 2014). Ini dengan jelas menjelaskan bahwa education missmatch adalah masalah sisi penawaran tenaga kerja. Selain mengidentifikasi alasan education missmatch, penting untuk mengidentifikasi dampak lulusan yang tidak sesuai dengan pendidikan, bahkan banyaknya education mismatch menjadikan pengangguran semakin meningkat (Badillo Amador, López Nicolás, \& Vila, 2013; Diem, 2014).

Ini juga tantangan besar yang harus dihadapi pemerintah Indonesia dalam upaya menciptakan tenaga kerja terampil sesuai dengan kompetensi yang dibutuhkan oleh dunia kerja, dalam hal ini adalah dunia usaha/dunia industri (DUDI) yang relevansinya menyangkut dua dimensi, yaitu sekolah dan dunia kerja atau masyarakat. Masalah banyaknya pengangguran salah satunya disebabkan oleh manajemen pendidikan yang kurang baik atau lulusannya yang tidak memiliki kompetensi, hal ini yang memunculkan dampak kekurangan tenaga kerja yang didominasi pada empat bidang keahlian, seperti maritim, pertanian, pariwisata dan ekonomi kreatif.

Link and match merupakan salah satu kebijakan Departemen Pendidikan dan Kebudayaan Republik Indonesia yang pernah ada dan dikembangkan untuk meningkatkan relevansi Sekolah Menengah Kejuruan (SMK) dengan kebutuhan dunia kerja, dunia usaha dan dunia industri khususnya. Tetapi nampaknya perlu upaya yang lebih maksimal dari Kemendikbud dalam menambah keberadaan SMK pada bidang keahlian yang dibutuhkan dan disesuaikan dengan potensi dan kebutuhan tenaga kerja di daerah.

Kebijakan link and match dianggap sebagai penggalian kompetensi yang dibutuhkan oleh pasar kerja pada masa yang akan datang yang diharapkan paradigma orientasi pendidikan tidak lagi supply minded tapi menjadi lebih demand minded (kebutuhan pasar). Kebijakan link and 
match terbagi menjadi dua sasaran, yaitu pada tingkat sekolah menengah, dan pada tingkat perguruan tinggi. Khususnya pada tingkat sekolah menengah, sasaran program pemerintah (DEPDIKNAS) mengubah proporsi siswa SMU vs SMK 70:30, menjadi 30:70. Sementara itu, pada tingkat perguruan tinggi diharapkan adanya peran industri untuk menciptakan pelatihan-pelatihan khusus bahkan bekerja sama untuk mendirikan institusi sesuai dengan jenis industri yang dikembangkan.

Kebijakan link and match diharapkan dapat menekan jumlah pengangguran lulusan perguruan tinggi dan sekolah menengah yang dari ke hari makin bertambah. Soemarso sebagai Ketua Dewan Pembina Politeknik dan juga dosen UI mengatakan bahwa konsep Link and Match antara lembaga pendidikan dan dunia kerja dianggap ideal, dimana konsep ini akan menciptakan keterkaitan antara pemasok tenaga kerja dengan penggunanya. Lebih lanjut Soemarso mengemukakan bahwa dengan adanya hubungan timbal balik membuat perguruan tinggi dapat menyusun kurikulum sesuai dengan kebutuhan kerja. Implementasi nyata dari kebijakan Link and Match adalah program magang. Perbaikan program magang, dimaksudkan agar industri juga mendapatkan manfaat, karena selama ini kesan yang ada bahwa yang mendapatkan manfaat dari magang adalah perguruan tinggi dan mahasiswa, sedangkan industri kebagian repotnya.

Berdasarkan keadaan tersebut, penjelasan secara konseptual terhadap masalahmasalah pengangguran tenaga terdidik sangat diperlukan, penjelasan yang bersifat konseptual diharapkan mampu mendudukkan permasalahan pada proporsi yang sebenarnya, khususnya tentang fungsi dan kedudukan sistem pendidikan dalam kaitannya dengan masalah ketenagakerjaan (Robts, 2013). Berangkat dari asumsi bahwa bertambahnya tingkat pengangguran disebabkan karena kegagalan sistem pendidikan, maka diperlukan adanya pendekatan-pendekatan tertentu dalam pendidikan dan konsep Link and Match perlu dihidupkan kembali dalam sistem pendidikan, agar supaya terintegrasi hubungan yang sinergi antara dunia pendidikan dengan dunia industri dimana keberhasilan sistem pendidikan di Indonesia mampu meningkatkan kualitas industri demikian puula sebaliknya industri ikut serta dalam pengembangan pendidikan kejuruan dan vokasi berbasis kompetensi, yang pada akhirnya akan memberikan manfaat bagi industri melalui tersedianya tenaga-tenaga kerja yang kompeten dan siap kerja, sehingga dapat mengurangi biaya dan resiko produksi, disamping meningkatkan daya saing industri.

\section{METODE PENELITIAN}

Penelitian ini menggunakan metode penelitian kualitatif dengan pendekatan penelitian studi kasus (case study). Studi kasus termasuk ke dalam penelitian analisis deskriptif yang mana penelitiannya terfokus pada suatu kasus tertentu yang diamati dan dianalisis secara cermat.Analisis ini dilakukan terhadap berbagai factor yang terkait dengan kasus yang diteliti, dalam penelitian ini kasus yang diteliti mengenai kebijakan link and match untuk mengatisipasi pengangguran tenaga terdidik. Penelitian ini memusatkan diri secara intensif terhadap kebijakan link and match dan mempelajarinya sebagai suatu 
kasus. Data yang diambil dalam penelitian ini berasal dari berbagai sumber dan hasil penelitian yang bersangkutan dengan kasus yang diselidiki.

\section{HASIL DAN PEMBAHASAN}

\section{Konsep dan Realisasi Kebijakan Link and Match antara Dunia Pendidikan dan Dunia Industri}

Program link and match telah dicanangkan sejak tahun 1989, namun demikian berdasarkan data statistik yang menunjukkan masih tingginya angka pengangguran, tingginya lowongan kerja yang tidak terisi, dan rendahnya kualitas pekerja, maupun hasil analisis data sakernas tersebut di muka, menunjukkan bahwa terdapat mismatch pendidikan dan kebutuhan keahlian pasar kerja yang masih tinggi, khususnya bagi tenaga kerja yang berpendidikan tinggi. Mismatch antara pendidikan dan pekerjaan mengakibatkan tingkat pendapatan yang lebih rendah, rendahnya kepuasan kerja, dan tingginya tingkat turnover pekerja, yang pada gilirannya mempengaruhi produktivitas pekerja (Holzer, 2013).

Mcgowan \& Andrews menunjukkan beberapa penelitian yang telah dilakukan tentang education-job mismatches yang menunjukan bahwa hal itu memberikan pengaruh yang relevan terhadap efisiensi investasi pendidikan baik publik maupun swasta, karena education job mismatches mempengaruhi upah dan juga keluaran serta hasil tenaga kerja lainnya, seperti kepuasan kerja (Faberman \& Mazumder, 2012; DavosKlosters, 2014), on the job training (Handel, 2014), mobilitas geografi (Sahin, Song, Topa, \& Violante, 2015), dan turn over pekerja
(Ferreira, Künn-Nelen, \& De Grip, 2017).

Sebagai contoh hasil dari penelitian Soesilowati (2009) diketahui bahwa kendala yang dihadapi dalam mengimplementasikan program link and match di dua daerah Batam (kepri) dan Banten.DiBatamprogramlink and match nampaknya di Batam belum optimal karena terdapat beberapa permasalahan. Pertama, masalah keterbatasan infrastruktur belajar mengajar. Pembangunan infrastruktur belum mencukupi dikarenakan kendala dana yang tersedia, hal ini dikarenakan perubahan dan perkembangan industry yang jauh lebih cepat dan berkembang sementara pendidikan tidak mudah melakukan penyesuaian dalam waktu singkat. Kedua, masalah kurikulum kurang sesuai dengan kondisi daerah/kondisi lokal. Ketiga, kurangnya koordinasi diantara stakeholders terkait. Keempat, belum ada pemetaan yang jelas dan pasti, berapa dan seperti apa tenaga kerja yang dibutuhkan dunia industri. Kelima, terbatasnya lowongan pekerjaan bagi lulusan SMU, sehingga banyak yang bekerja sebagai operator di industri, padahal mereka tidak memiliki keahlian yang sesuai dengan latar belakang pendidikannya. Ketujuh, lulusan SMK masih banyak yang bekerja di luar bidangnya (sebanyak 50 persen) akibat keterbatasan lahan kerja yang sesuai dengan bidangnya, dan keengganan mereka untuk diberikan pekerjaan yang sama dengan lulusan SMU bekerja sebagai operator.

Dari hasil penelitian di atas dapat dilihat bahwa masih banyak aspek yang harus diperbaiki dari pemerintah. Dari aspek pertama sangat berkaitan dengan aspek lainnya. Jika seperti ini apakah kebijakan pemerintah dalam hal ini kebijakan link 
and match dapat diimplementasikan? yakni sosial dan sumber dayanya.

Jawabannya tentu saja tidak. Pemerintah

harus berfokus setidaknya pada dua aspek

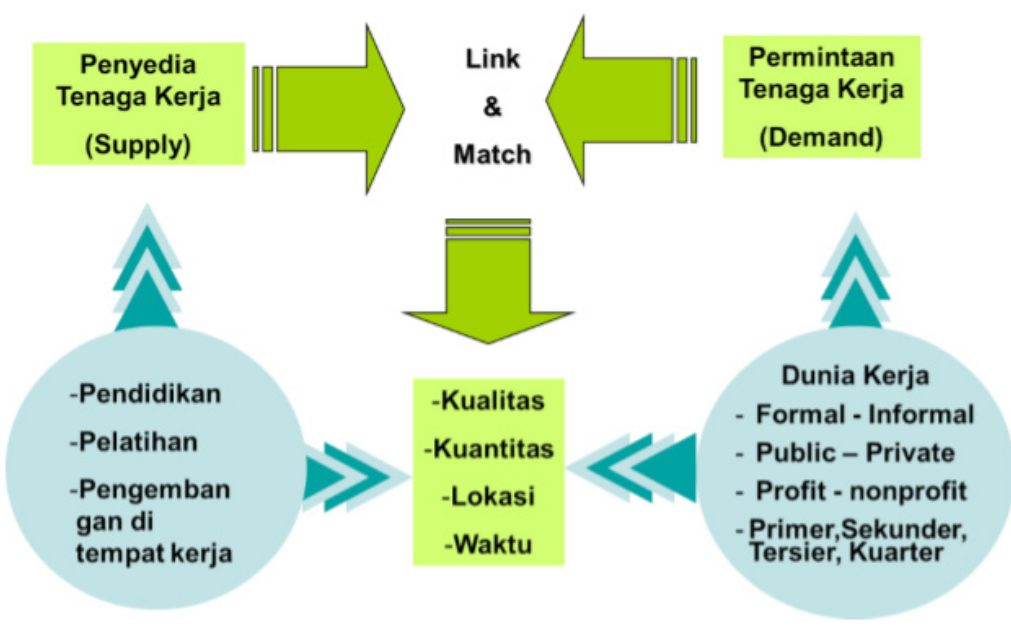

Gambar 1

Konsep Link and Match

Pendidikan formal maupun nonformal hidup masyarakat. Sehingga kebijakan link tentunya bertujuan untuk menciptakan output yang terbaik dan menghasilkan outcome yang dapat berdampak positif bagi kepentingan pendidikan dan organisasi tersebut. Salah satu tujuan pendidikan kejuruan adalah tempat untuk menyediakan tenaga kerja yang terampil, ahli, dan memiliki skill yang terbaik (Gaeta, Lavadera, \& Pastore, 2017). Kewajiban para stakeholder adalah bagaimana memanajen sistem pendidikan sesuai dengan kebutuhan industri dan kebutuhan masyarakat demi mengurangi tingkat pengangguran dari lulusan pendidikan kejuruan yang telah dipaparkan sebelumnya (Russo, 2017). Sedangkan DUDI dunia usaha dan dunia industri berkembang pesat setiap waktu, selalu didesak untuk dapat memenuhi kebutuhan masyarakat, sehingga Antara pendidikan kejuruan yang menciptakan lulusan yang berkompeten memiliki keterkaitan dengan dunia industri yang memerlukan sumber daya manusia yang handal demi memenuhi kebutuhan and match ini memang sangat dibutuhkan.

Dalam implementasinya tahun 2016 Kementerian Perindustrian berkomitmen membangun kompetensi sumber daya manusia (SDM) Indonesia yang sesuai dengan kebutuhan dunia kerja saat ini sekaligus untuk mendorong pertumbuhan industri nasional yang berkelanjutan. Wujud komitmen ini ditunjukkan melalui penandatanganan bersama Nota Kesepahaman (MoU) lima menteri tentang Pengembangan Pendidikan Kejuruan dan Vokasi Berbasis Kompetensi yang Link and Match dengan Industri. Kelima Menteri tersebut adalah Menteri Perindustrian Airlangga Hartarto, Menteri Pendidikan dan Kebudayaan Muhadjir Effendy, Menteri Riset, Teknologi, dan Pendidikan Tinggi Mohamad Nasir, Menteri Ketenagakerjaan M. Hanif Dhakiri, serta Menteri Badan Usaha Milik Negara Rini M. Soemarno. Penandatanganan MoU tersebut merupakan tindak lanjut Instruksi Presiden Nomor 9 Tahun 2016 tentang Revitalisasi 
Sekolah Menengah Kejuruan (SMK) dalam rangka peningkatan kualitas dan daya saing SDM Indonesia.

Selain itu juga implementasi arahan Presiden Joko Widodo pada rapat terbatas tentang pendidikan dan pelatihan vokasi. Dalam menghadapi era industri 4.0 yang melibatkan unsur digital dalam setiap rantai nilai proses manufakturnya, para lulusan yang nantinya akan bekerja dituntun untuk mampu beradaptasi dengan perkembangan teknologi. Oleh karena itu menurut Airlangga industri juga diharapkan perannya untuk memberikan masukan terhadap kurikulum pendidikan sesuai dengan perkembangan teknologi serta menyediakan fasilitas praktik dan pemagangan bagi siswa/mahasiswa dan guru/dosen sehingga baik bagi pendidik dan peserta didik. Namun MoU yang dilakukan pemerintah ini hanya meliputi pendidikan kejuruan yang bekerja sama dengan industri manufaktur, belum termasuk pada industri pariwisata, seni, kesehatan, dan sumber daya alam.

Perlu komitmen yang kuat dari lima menteri yang telah menandatangani MoU agar terealisasi secara konkret untuk mewujudkan link and match dalam penerapan pendidikan vokasi dengan dunia industri. "Dari tingkat menteri sampai jajaran di bawahnya harus tetap kompak. Selain itu, harus ada gerak cepat setelah MoU sehingga komitmen ini membantu program pemerintah. Pun diharapkan kelima menteri tersebut berkomitmen untuk melaksanakan tanggung jawabnya masing-masing, dan ke depannya bisa ditambah lagi kementerian lainnya seperti Kementerian Perhubungan dan Kementerian Pariwisata. "Bidang yang menjadi prioritas revitalisasi pendidikan dan pelatihan vokasi di antaranya adalah industri, kemaritiman, pariwisata, dan pertanian. Oleh karena itu, pemerintah menyiapkan pendidikan kejuruan dan vokasi sebagai solusi untuk meningkatkan kompetensi SDM Indonesia agar mampu bersaing secara global.

\section{Urgensi Kebijakan Link and Match dalam Pendidikan}

Link and match adalah kebijakan Departemen Pendidikan dan Kebudayaan Republik Indonesia yang dikembangkan untuk meningkatkan relevansi Sekolah Menengah Kejuruan (SMK) dengan kebutuhan dunia kerja, dunia usaha serta dunia industri khususnya. Konsep kebijakan Link and Match antara dunia pendidikan dan dunia kerja diharapkan dapat menekan pengangguran lulusan pendidikan kejuruan yang dari hari ke hari semakin bertambah.

Dari gambar 2 dapat diketahui bahwa tantangan yang dihadapi pemerintah dan tentunya masyarakat Indonesia adalah MEA, yang memungkinkan persaingan tenaga kerja secara bebas sesama anggota ASEAN. Oleh karena itu untuk menjawab tantangan MEA dalam menciptakan tenaga terampil dalam dunia industri yakni dimulai dengan pengembangan pendidikan kejuruan dengan strateginya adalah kebijakan Link and Match tersebut, sehingga bagaimana industri yang berada di Indonesia untuk setidaknya merekrut SDM dalam negeri, yang tentunya sudah terampil dan memiliki skill yang telah di bentuk dari program-program pendidikan kejuruan yang telah ditempuh, demi memenuhi kebutuhan tenaga kerja seperti yang tercantum pada gambar 3 . 


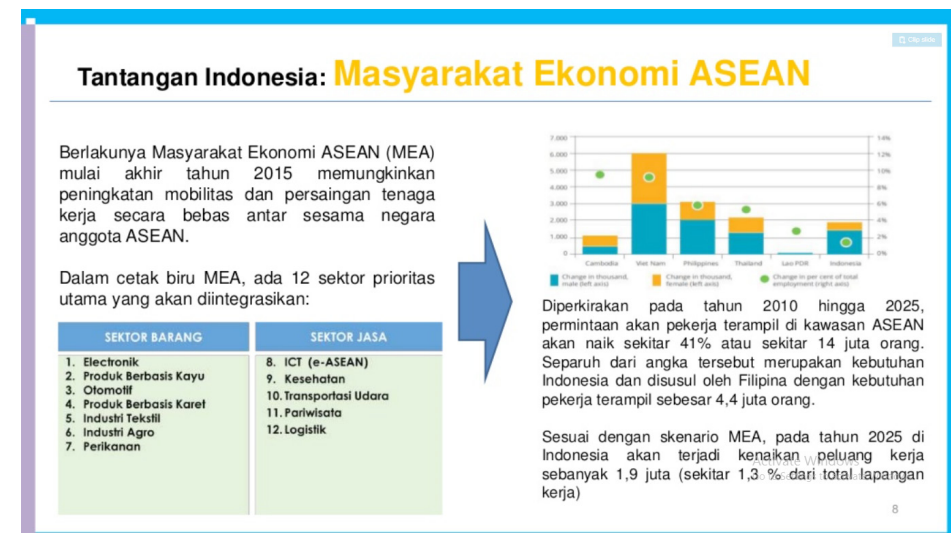

Gambar 2

Tantangan Masyarakat Ekonomi Asean

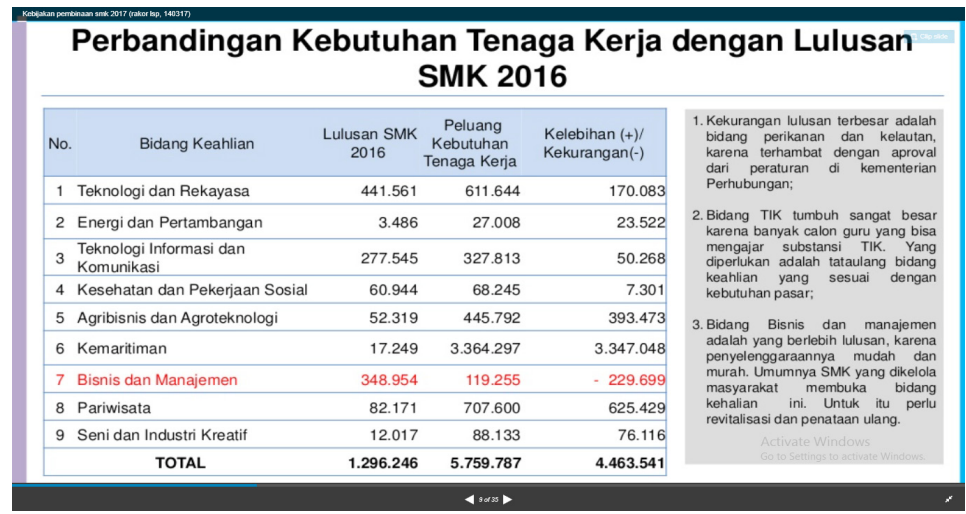

Gambar 3

Perbandingan Kebutuhan Tenaga Kerja dengan Lulusan SMK Tahun 2016

Idealnya terdapat tiga komponen yang harus bergerak simultan untuk menyukseskan program Link and Match yaitu: Pendidikan Kejuruan dan Perguruan Tinggi, dunia kerja (perusahaan) dan pemerintah. Jika kebijakan Link and Match berjalan baik, pemerintah juga diuntungkan dengan berkurangnya beban pengangguran (terdidik). Karena itu, seyogianya pemerintah secara serius menjaga iklim keterkaitan dan mekanisme implementasi ilmu dari perguruan tinggi ke dunia kerja sehingga diharapkan program Link and Match ini berjalan semakin baik dan semakin mampu membawa manfaat bagi semua pihak.

Manfaat yang dapat dipetik dari pelaksanaan Link and Match sangat besar. Karena itu, diharapkan semua stakeholders dunia pendidikan bersedia membuka mata dan diri dan mulai bersungguh-sungguh menjalankannya. Pendidikan kejuruan harus lapang dada menerima bidang keahlian (kompetensi) yang dibutuhkan dunia kerja sebagai materi pembelajaran. Perusahaan juga harus membuka pintu selebar-lebarnya bagi lulusan pendidikan kejuruan yang ingin magang (bekerja) di perusahaan tersebut. Sedangkan Pemerintah harus serius dan tidak semata memandang program Link and Match (keterkaitan dan kesepadanan) sebagai proyek belaka.

\section{Strategi dalam Mewujudkan Kebijakan}

\section{Link and Match}

Dalam menjalankan sebuah kebijakan perlu terlebih dahulu menganalisis hal-hal yang mendasari kebijakan itu dibuat, beberapa pendekatan dalam mewujudkan kebijakan 
Link and Match Antara lain;

\section{Pendekatan Sosial}

Pendekatan sosial merupakan pendekatan yang didasarkan atas keperluan masyarakat pada saat ini. Pendekatan ini menitik beratkan pada tujuan pendidikan dan pada pemerataan kesempatan dalam mendapatkan pendidikan (Usman, 2012:56). Menurut A.W. Gurugen pendekatan sosial merupakan pendekatan tradisional bagi pembangunan pendidikan dengan menyediakan lembagalembaga dan fasilitas demi memenuhi tekanan-tekanan untuk memasukan sekolah serta memungkinkan pemberian kesempatan kepada murid dan orang tua secara bebas (Indar, 2014:30). Sebagai contoh penerapan pendekatan ini adalah diterapkannya sistem ganda melalui kebijakan Link and Match.

Namun dalam pendekatan ini ada beberapa kelemahan dalam pendekatan ini diantaranya adalah 1) Pendekatan ini mengabaikan masalah alokasi dalam skala nasional, dan secara samar tidak mempermasalahkan besarnya sumber daya pendidikan yang dibutuhkan karena beranggapan bahwa penggunaan sumberdaya pendidikan yang terbaik adalah untuk segenap rakyat Indonesia; 2) Pendekatan ini mengabaikan kebutuhan ketenagakerjaan (man power planning) yang diperlukan dimasyarakat sehingga dapat menghasilkan lulusan yang sebenarnya kurang dibutuhkan masyarakat; 3) Pendekatan ini cenderung hanya menjawab pemerataan pendidikan saja sehingga kuantitas lebih diutamakan dari pada kualitasnya (Indar, 2014: 236).

\section{Pendekatan Ketenagakerjaan}

Di dalam pendekatan ketenagakerjaan ini kegiatan-kegiatan pendidikan diarahkan kepada usaha untuk memenuhi kebutuhan nasional akan tenaga kerja pada tahap permulaan pembangunan tentu saja memerlukan banyak tenaga kerja dari segala tingkatan dan dalam berbagai jenis keahlian. Dalam keadaan ini kebanyakan negara mengharapkan supaya pendidikan mempersiapkan dan menghasilkan tenaga kerja yang terampil untuk pembangunan, baik dalam sektor pertanian, perdagangan, industri dan sebagainya (Jusuf Enoch, 1992: 90). Untuk itu perencana pendidikan harus mencoba membuat perkiraan jumlah dan kualitas tenaga kerja dibutuhkan oleh setiap kegiatan pembangunan nasional. Dalam teorinya pendekatan ini lebih mengutamakan keterkaitan lulusan sistem pendidikan dengan tuntutan akan kebutuhan tenaga kerja, didalam pendekatan ini juga mempunyai kelemahan, dimana ada tiga kelemahan yang paling utama, yaitu 1) Mempunyai peranan yang terbatas dalam perencanaan pendidikan, karena pendekatan ini mengabaikan keberadaaan sekolah umum karena hanya akan menghasilkan pengangguran saja, pendekatan ini lebih mengutamakan sekolah menengah kejuruan untuk memenuhi kebutuhan kerja; 2) Menggunakan klasifikasi rasio permintaan dan persediaan; 3) Tujuan dari pada pendekatan ini hanyalah untuk memenuhan kebutuhan tenaga kerja, disisi lain tuntutan dunia kerja berubah-ubah sesuai dengan cepatnya perubahan zaman (Usman, 2012:59).

Pada hakekatnya, program dan kegiatan pembangunan pendidikan kejuruan diorientasikan pada tujuan strategis pembangunan pendidikan menengah kejuruan yang mengacu pada Rencana Strategis 
Kementerian Pendidikan dan Kebudayaan, yaitu "tersedianya dan terjangkaunya layanan pendidikan menengah kejuruan yang bermutu, relevan, dan berkesetaraan disemua provinsi, kabupaten, dan kota". Pengukuran ketercapaian tujuan strategis pembangunan pendidikan menengah kejuruan tersebut dilakukan dengan ketercapaian sejumlah sasaran strategis yang menggambarkan kondisi yang harus dicapai pada tahun 2014 . Sasaran strategis dari tujuan strategis tersebut di atas adalah sebagai berikut 1) APK nasional melampaui target nasional $(85 \%)$; 2) Sekurang-kurangnya 66\% SMK berakreditasi; 3) Sekurang-kurangnya 60\% kabupaten/kota memiliki SMK dan SMK SBI atau RSBI; 4) 0\% SMK bersertifikat ISO 9001:2008; 5) Sekurang-kurangnya 90\% SMK melaksanakan e-pembelajaran (e-learning); 6) $70 \%$ Lulusan SMK bekerja pada Tahun Kelulusan; 8) $85 \%$ SMK menyediakan layanan pembinaan pengembangan kewirausahaan; 9) Menurunnya disparitas gender yang ditunjukkan dengan rasio kesetaraan gender menjadi $95 \%$; 10) Seluruh SMK menerapkan pembelajaran yang membangun karakter.

Dalam lingkup link and match sebelumya telah dilokalisir beberapa induk masalah utama yang melahirkan berbagai masalah lainnya yakni, masalah kurang/tidak adanya kerjasama yang efektif diantara dunia pendidikan tinggi, pemerintah, dan industri menyangkut aspek-aspek terutama penyusunan kurikulum termasuk magang, pemberdayaan dunia pendidikan tinggi (infrastruktur, SDM, dan riset), tidak adanya road map informasi peta tenaga kerja industri (alokasikebutuhan dan rencananya spesifikasi jenis dan mutu kompetensi), dan peningkatan Investasi dunia industri. Masalah di atas terkait dengan ketidakjelasan payung hukum beserta peraturan pelaksanaan yang rinci tentang penanganan masalah link and match dan otoritas institusi yang tegas dan berdaya (kewenangan dan sumberdaya memadai) yang dapat menjamin/mewajibkan/memaksa kerjasama ketiga pihak terkait diatas berjalan efetif, terukur, dan berkelanjutan. Berdasarkan klasifikasi induk masalah link and match, maka strategi sederhana yang diperkirakan efektif jika diimplementasikan menurut Soesilowati (2009), antara lain:

1) Perlu dikaji dan ditata kembali berbagai produk hukum baik Undang-undang, Peraturan Pemerintah, Keputusan/ peraturan Presiden, Keputusan/peraturan Menteri, sampai perda-perda yang mengatur/memayungi aspek link and match antara dunia pendidikan tinggi dan industri. Dalam hal ini yang terpenting adalah payung hukum beserta SOP tentang kewajiban bekerjasama beserta sangsinya diantara dunia perguruan tinggi, dunia industri (dan assosiasiassosiasinya), dan pemerintah (daerah dan pusat).

2) Perlu ditentukan institusi otoritas link and match (ditunjuk yang sudah ada seperti Dirjen Dikti atau Kadin atau dibentuk baru yang mewakili ketiga pihak di atas) seperti program CO-OP yang sudah ada disertai mitranya di daerah secara tegas dalam payung hokum di atas yang dibarengi pemberian power sumberdaya (terutama sumberdaya keuangan dan SDM) yang memadai.

3) Perlu dirinci uraian tugas pokok dan 
fungsi Tupoksi) institusi serta mekanisme kerjanya yang lebih terukur. Dalam hal ini termasuk uraian substansi kerjasama yang efektif, terukur, dan berkelanjutan terutama menyangkut penyusunan kurikulum, program magang, riset, penyusunan road map sektoral dan regional alokasi lowongan kerja dan rencana/prediksi ke depan. Berhubung adanya ekses supply tenaga kerja, maka perlu juga diterapkannya kurikulum tambahan disetiap jenis kompetensi yaitu tentang kewirausahaan, sehingga lulusan perguruan tinggi yang tetap tidak terserap bisa menciptakan lapangan kerja sendiri.

4) Strategi lainnya adalah penegakan law enforcement agar semua aktivitas perbaikan link and match sesuai perintah undang-undang dapat berjalan baik.

5) Untuk mengurangi ekses supply tenaga kerja berpendidikan tinggi perlu kebijakan pemerintah yang mendorong perluasan investasi pada industri-industri baru.

\section{KESIMPULAN}

Kebijakan pendidikan adalah suatu penilaian terhadap sistem nilai dan faktor-faktor kebutuhan situasional, yang dioperasikan dalam sebuah lembaga sebagai perencanaan umum untuk panduan dalam mengambil keputusan, agar tujuan pendidikan yang diinginkan bisa dicapai. Kebijakan diperoleh melalui suatu proses pembuatan kebijakan. Pembuatan kebijakan (policy making) adalah terlihat sebagai sejumlah proses dari semua bagian dan berhubungan kepada sistem sosial dalam membuat sasaran sistem. Proses pembuatan keputusan memperhatikan faktor lingkungan eksternal, input (masukan), proses (transformasi), output (keluaran), dan feedback (umpan balik) dari lingkungan kepada pembuat kebijakan (Iammarino \& Marinelli, 2014).

Link and Match (keterkaitan dan kesepadanan) sebagai keluaran dari sebuah kebijakan, merupakan konsep keterkaitan antara lembaga pendidikan dengan dunia kerja, atau dengan kata lain Link and Match ini adalah keterkaitan antara pemasok tenaga kerja dengan penggunanya. Dengan adanya keterkaitan ini maka pendidikan sebagai pemasok tenaga kerja dapat mengadakan hubungan-hubungan dengan dunia usaha/ industri. Dengan link dan match ini suatu lembaga khususnya Pendidikan Kejuruan bisa mengadakan kerja sama dengan pihak lain khususnya dengan perusahaan atau industri agar mahasiswa bisa magang di perusahaan tersebut. Dengan adanya Link and Match tersebut Pendidikan Kejuruan dapat mengetahui kompentensi (keahlian) apa yang paling dibutuhkan dunia kerja dan kompetensi apa yang paling banyak dibutuhkan dunia kerja.

Adapun pendekatan yang digunakan untuk mewujudkan Link and Match adalah pendekatan sosial dan pendekatan ketenagakerjaan. Pendekatan sosial merupakan pendekatan yang didasarkan atas keperluan masyarakat yang mana pendekatan ini menitik beratkan pada tujuan pendidikan dan pemerataan kesempatan dalam mendapatkan pendidikan. Sedangkan Pendekatan ketenagakerjaan merupakan pendekatan yang mengutamakan kepada keterkaitan lulusan sistem pendidikan 
dengan tuntutan terhadap tenaga kerja pada berbagai sektor pembangunan dengan tujuan yang akan dicapai adalah bahwa pendidikan itu diperlukan untuk membantu lulusan memperoleh kesempatan kerja yang lebih baik sehingga tingkat kehidupannya dapat diperbaiki.

Pendidikan formal dianggap sebagai penentu dalam menunjang pertumbuhan ekonomi, dan titik temu antara pendidikan dan pertumbuhan ekonomi adalah produktivitas kerja, dengan asumsi bahwa semakin tinggi mutu pendidikan, semakin tinggi produktivitas kerja, semakin tinggi pula pengaruhnya terhadap pertumbuhan ekonomi suatu masyarakat.

Sesungguhnya banyak upaya peningkatan link and match yang telah dilakukan dengan benar, namun karena upaya tersebut kurang komprehensif, konsisten, dan terukur serta tidak ditopang oleh hukum yang jelas, maka upaya ini kembali tergilas besarnya masalah yang muncul. Nampaknya strategi peningkatan link and match yang efektif adalah perlunya payung hukum beserta sangsinya yang mengatur terjaminnya efektivitas hubungan interaksi secara terukur, menyeluruh, dan berkelanjutan antara dunia pendidikan tinggi, industri, dan pemerintah dalam menangani masalah link and match ini. Untuk menyusun strategi jangka panjang yang rinci dan komprehensif tentu masih diperlukan penelitian besar yang mendalam dengan lingkup yang memadai.

\section{DAFTAR PUSTAKA}

Badillo Amador, L., López Nicolás, Á., \& Vila, L. E. (2013). Education and competence mismatches: job satisfaction consequences for workers. XVI Jornadas ASEPUMA - IV Encuentro Internacional , 1(16), $105-123$.

Boudarbat, B., \& Chernoff, V. (2015). The Determinants of Education-Job Match among Canadian University Graduates. IZA Discussion Paper , 43(6), 781-793.

Davos-Klosters. (2014). Matching Skills and Labour Market Needs Building Social Partnerships for Better Skills and Better Jobs. World Economic Forum Global Agenda Council on Employment, 1(1), 20-35.

Diem, A. (2014). Overeducation among Graduates from Universities of Applied Sciences: Determinants and Consequences. International Journal of Economics, 2(1), 27-43.

Faberman, R. J., \& Mazumder, B. (2012). Is there a skills mismatch in the labor market? The Federal Reserve Bank of Chicago, 4(3), 40-55.

Ferreira, M., Künn-Nelen, A., \& De Grip, A. (2017). Work-Related Learning and Skill Development in Europe: Does Initial Skill Mismatch Matter? Research in Labor Economics, 3(34), 345-407.

Gaeta, G. L., Lavadera, G. L., \& Pastore, F. (2017). Much Ado about Nothing? The Wage Penalty of Holding a $\mathrm{PhD}$ Degree but Not a PhD Job Position. Research in Labor Economics, 10(1), 243-277.

Handel, M. J. (2014). Skills Mismatch in the Labor Market. Annual Review of Sociologi JSTOR, 29(135), 65-76.

Hersch, J. (2012). Education Match and Job Match. The Review of Economics and Statistics, 73(1), $650-664$.

Holzer, H. J. (2013). Skill Mismatches in Contemporary Labor Markets: How Real? And What Remedies? School of Public Policy, 1(2), 1-10.

Iammarino, S., \& Marinelli, E. (2014). Education-job (mis)match and interregional migration. Italian university graduates' transition to work. EuroLIO Geography of Innovation, 4(3), 54-76.

Indar, D. (2014). Perencanaan Pendidikan Strategi dan Implementasinya (5th ed.). Surabaya: Karya Aditama.

Mcgowan, M. A., \& Andrews, D. (2015). The Future Of Productivity: Main Background Papers Labour Market Mismatch And Labour Productivity: Evidence From Piaac Data. Economics Departement Working Papers No 1209, 27(1), 1-51. 
Mf, R., Senarath, S. A. C. L., \& Patabendige, S. S. J. (2014). Job-Education Mismatch Among the Graduates: A Sri Lankan Perspective. Ruhuna Journal of Management and Finance, 1(2).

Robst, J. (2017). Education and job match: The relatedness of college major and work. Economics of Education Review, 26, 397-407.

Robts, J. (2013). Career Mobility, Job Match and Over education. Eastern Economic Journal, 21(4).

Russo, G. (2017). Job Design and Skill Development in the Workplace. Research in Labor Economics, 5(4), 409-445.

Sahin, A., Song, J., Topa, G., \& Violante, G. L. (2015). Measuring Mismatch in the U.S. Labor Market. Journal of Paris School of Economics, 10(9), 9-19.

Sloane, P. J. (2013). Much Ado About Nothing? What Does The Over-Education Literature Really Tell Us? Overeducation in Europe: Current Issues in Theory and Policy, 45(3), 234-254.

Soesilowati, E. S. (2009). Link And Match Dunia Pendidikan Dan Industri Dalam Meningkatkan Daya Saing Tenaga Kerja Dan Industri. Jakarta: LIPI Press, Pusat Penelitian Ekonomi Lembaga Ilmu Pengetahuan Indonesia.

Usman, H. (2012). Manajemen: Teori, Praktik, dan Riset Pendidikan. Jakarta: Bumi Aksara.

Walters, D. (2014). The Relationship Between Post secondary Education and Skill: Comparing Credentialism with Human Capital Theory. The Canadian Journal of Higher Education, 90(2), 97-124. 